\title{
A Foreign Cases Study of the Deep Borehole Disposal System for High-Level Radioactive Waste
}

\section{고준위 방사성폐기물 심부시추공 처분시스템 개발 해외사례 분석}

\author{
Jongyoul Lee*, Geonyoung Kim, Daeseok Bae, and Kyeongsoo Kim \\ Korea Atomic Energy Research Institute, 111 Daedeokdaero 989, Yuseong-Gu, Daejon, Korea \\ 이종열*, 김건영, 배대석, 김경수 \\ 한국원자력연구원, 대전광역시 유성구 대덕대로 989 번길 111
}

(Received November 14, 2013 / Revised January 13, 2014 / Approved January 28, 2014)

If the spent fuels or the high-level radioactive wastes can be disposed of in the depth of $3 \sim 5 \mathrm{~km}$ and more stable rock formation, it has several advantages. For example, (1)significant fluid flow through basement rock is prevented, in part, by low permeability, poorly connected transport pathways, and (2)overburden self-sealing. (3)Deep fluids also resist vertical movement because they are density stratified and reducing conditions will sharply limit solubility of most dose-critical radionuclides at the depth. Finally, (4) high ionic strengths of deep fluids will prevent colloidal transport. Therefore, as an alternative disposal concept to the deep geological disposal concept(DGD), very deep borehole disposal(DBD) technology is under consideration in number of countries in terms of its outstanding safety and cost effectiveness. In this paper, for the preliminary applicability analyses of the DBD system for the spent fuels or high level wastes, the DBD concepts which have been developed by some countries according to the rapid advance in the development of drilling technology were reviewed. To do this, the general concept of DBD system was checked and the study cases of foreign countries were described and analyzed. These results will be used as an input for the analyses of applicability for DBD in Korea.

Keywords: Spent fuels, High-level radioactive wastes, Deep geological disposal(DGD), Deep borehole disposal(DBD), Safety, Alternative Technology

사용후핵연료를 포함하는 고준위 방사성폐기물을 지질학적 조건이 안정적인 지하 $3 \sim 5 \mathrm{~km}$ 의 심도에 처분할 수 있다면 다음 과 같은 많은 장점이 있는 것으로 평가되고 있다. 즉, (1)암반 수리전도도가 매우 낮아 지하수가 생태계까지 도달하는데 속 도가 현저히 감소되며, (2)상부층 두께로 인하여 생태계와의 이격거리 확보에 유리하고, (3)지하수가 환원상태이므로 핵종 의 용해도가 매우 낮을 뿐만 아니라 (4)오랜 연령의 지하수에서는 핵종이 흡착된 콜로이드 생성과 이동이 극히 제한된다는 점이다. 이와 관련하여 심부시추공 처분(Deep Borehole Disposal) 연구는 심층 처분(Deep Geological Disposal) 시스템에 대한 이상적인 처분 대안기술로서 꾸준하게 진행되어 왔다. 본 논문에서는 최근 심부 시추기술이 비약적으로 발전됨에 따 라 의미있게 연구가 진행되고 있는 심부시추공 처분시스템을 국내 적용하기 위한 초기 단계로서 해외의 심부시추공 처분시 스템 기술개발 사례를 분석하였다. 이를 통하여 심부시추공 처분에 대한 일반적인 개념과 심부시추공 처분시스템 개념을 도 출한 연구사례를 국가별로 정리하였다. 이들 분석결과는 향후 심부시추공 처분기술의 국내 적용을 위한 입력자료로서 유용 하게 활용될 수 있을 것이다.

중심단어: 사용후핵연료, 고준위폐기물, 심층처분, 심부시추공처분, 안전성, 대안기술

* Corresponding Author.

Jongyoul Lee, Korea Atomic Energy Research Institute, E-mail: njylee@kaeri.re.kr, Tel: +82-42-868-2071 


\section{1. 서 론}

사용후핵연료 또는 고준위폐기물의 안전한 처분을 위하 여 지난 수십 년 동안 많은 나라들이 다양한 처분대안을 분석 하여 왔으며, 그 결과 현재 기술로 실현할 수 있는 가장 안전 한 방법으로 고려하고 있는 심층처분(DGD : Deep Geological Disposal) 기술이 개념개발 및 실증연구를 거쳐 상용화 단계에 진입하였다. 이러한 심층처분 기술은 고준위폐기물 을 장기간 환경으로부터 격리하기 위하여 심도 $500 \mathrm{~m}$ 깊이 의 암반에 건설하는 터널형 처분시스템으로서 대표적인 개 념은 스웨덴에서 개발한 KBS-3개념이 있으며, 핀란드와 스 웨덴에서는 심층처분 방식의 처분시설 건설에 대한 인허가 단계에 있다. 심층처분기술이 가장 안전한 방식으로 고려되 고 있고 상용화단계에 있음에도 불구하고, 심부시추공 처분 (DBD: Deep Borehole Disposal)은 심층처분 방식에 대한 대안으로서 꾸준히 관심을 받아오고 있는 방법이다. 즉, 근 래 심부시추 기술의 비약적인 발전으로 보다 안전하고 비용 효율적인 처분기술이라고 개념적으로 평가되고 있는 대안 기술로서 심부시추공 처분기술에 대한 연구가 의미있게 진 행되고 있다.

스웨덴의 경우 원자력폐기물 관리방안 검토를 위한 비정부 기관(MKG: Swedish NGO Office of Nuclear Waste Review) 과 방사성폐기물 관리사업기관 (SKB : Swedish Nuclear Fuel and Waste Management Company)은 심부시추공 처분 시스 템에 대한 연구개발의 지속성 문제에 대한 보고서를 발간[1]하 였고, 국가 자문기관(KASAM: Swedish National Council for Nuclear Waste)은 이에 대한 투명한 정보제공을 위하여 2007 년 공청회를 개최한 바 있다[2]. 또한, 미국의 경우, $\mathrm{YMP}$ (Yucca Mountain Project) 중지로 인하여 Sandia국립연구소와 MIT 대학을 중심으로 심부시추공 처분 개념에 대한 연구를 수행해 왔다. 특히, 자문위원회인 블루리본위원회(BRC : Blue Ribbon Committee)의 권고[3]에 의한 4개의 심층연구 항목(Shale/ clay, Granite, Salt, Deep borehole)의 하나로 본격적인 연구 를 수행 중에 있으며, 심부시추공 처분개념에 대한 기준설계 개 념을 도출하고 이의 실증을 위한 계획[4]을 수립하였다.

본 논문에서는 터널형 처분시스템인 심층처분기술의 유력 한 대안으로 고려되고 있는 심부시추공 처분개념에 대한 국내 에서의 적용성 평가 및 심층 분석에 필요한 기초단계로서 관련 기술에 대한 일반적인 개념을 검토하였다. 또한, 스웨덴, 미국,
네덜란드 등 화강암반 및 암염돔을 기반암으로 하여 심부시추 공 처분시스템을 도출한 주요국의 연구사례를 분석하였다. 이 들 분석결과는 이 기술의 국내 적용성 분석을 위한 입력자료로 서 유용하게 활용될 수 있을 것으로 판단된다.

\section{2. 심부시추공 처분 개념}

지질학적 조건이 더 안정적인 지하 $3 \sim 5 \mathrm{~km}$ 의 심도에 고 준위폐기물을 처분(Fig. 1)할 수 있다면, 1) 생태계와의 이격 거리 확보에 유리하고, 2) 암반의 수리전도도가 매우 낮아 지 하수의 생태계 도달 속도가 현저히 감소하고, 3) 지하수가 환 원상태여서 핵종의 용해도가 매우 낮으며, 4) 연령이 오래된 지하수에서는 핵종이 흡착된 콜로이드의 생성과 이동이 극히 제한된다는 장점이 있을 것으로 평가되고 있어, 이 심부시추 공 처분개념이 이상적인 처분 대안기술로 평가되고 있다[5].

심부시추공 처분 기술은 지표에서 결정질 암반의 지하 $5 \mathrm{~km}$ 심도까지 하나의 시추공 또는 다수로 구성된 시추공 배 열을 굴착하여 하부 심도 $3 \sim 5 \mathrm{~km}$ 인 $2 \mathrm{~km}$ 구간에 공학적방벽 개념을 도입하여 사용후핵연료 또는 재처리로부터 발생한 고준위폐기물을 적재한 처분용기를 처분하고 처분구간 상부 인 심도 $3 \mathrm{~km}$ 에서 지표까지는 벤토나이트, 아스팔트 등으로 밀봉하여 지표 생태계와 장기간 동안 안전하게 격리시키는

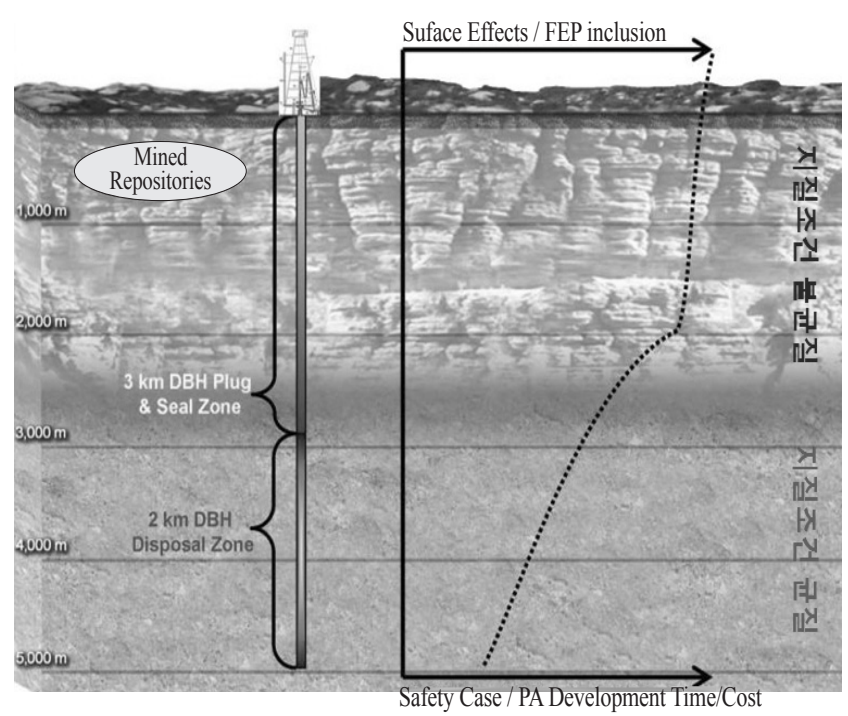

Fig. 1. Concept of Geological Condition for DBD[5]. 


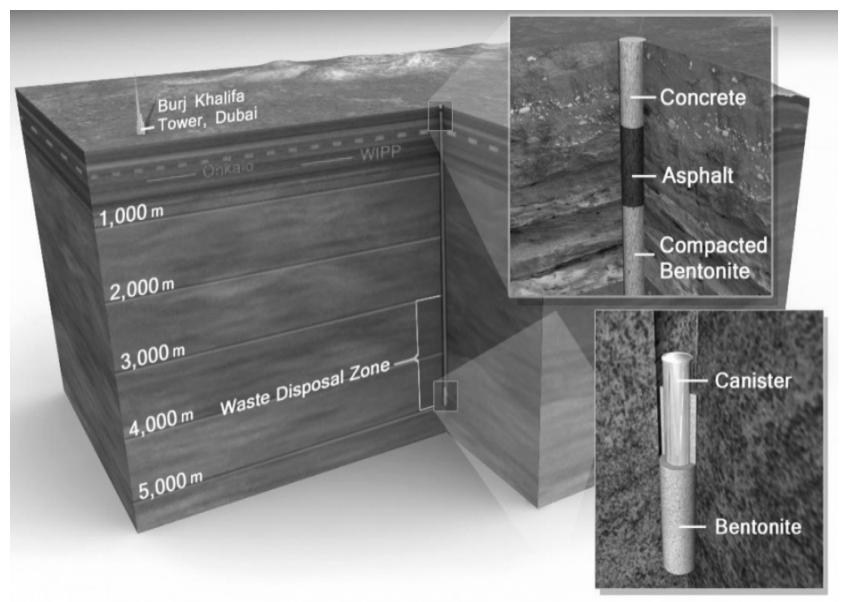

Fig. 2. General Concept of DBD[6].

개념으로서 일반화된 심부시추공 처분개념은 Fig. 2에 도시 된 바와 같다[6]. 심부시추공 처분시스템에서의 핵심기술은 대구경의 시추공을 처분심도까지 굴착하는 기술, 심부지하 의 지질특성을 조사분석하는 기술, 처분용기를 포함하는 공 학적 방벽 개념도출과 처분용기 취급 방법/장비 등 처분시스 템 개념개발 기술, 그리고 처분시스템에 대한 성능 및 안전성 평가 기술 등을 포함한다.

\section{1 심부지층 시추기술}

대구경의 시추공을 처분심도까지 굴착하여야 하는 기술 의 비약적인 발전은 석유산업 뿐만 아니라 과학적인 목적을 중심으로 이루어졌으며, 이에 따라 KBS-3 타입의 터널형 처 분시스템에 대한 대안으로서 심부시추공 처분기술에 대한 연구가 활발하게 진행 될 수 있는 바탕이 되었다. Fig. 3은 실 제 건설 경험이 있는 시추공의 지름과 심도를 함수로 하는 도 표이다[7]. 주된 결론은 심부시추공 처분을 위해 제안된 깊이 인 $5 \mathrm{~km}$ 정도까지 $40 \sim 50 \mathrm{~cm}$ 지름의 시추공을 굴착하는 것 은 매우 주요한 도전과제라는 것이다.

\section{2 심부지하 조사분석 기술}

심부지하의 지질특성 조사 분석은 공경이 작은 시추공 굴착을 선행하여 조사와 시험을 수행하는 것이 처분공 굴착 을 위한 굴착 비트의 선정과 처분공 굴착기술의 결정에 유익

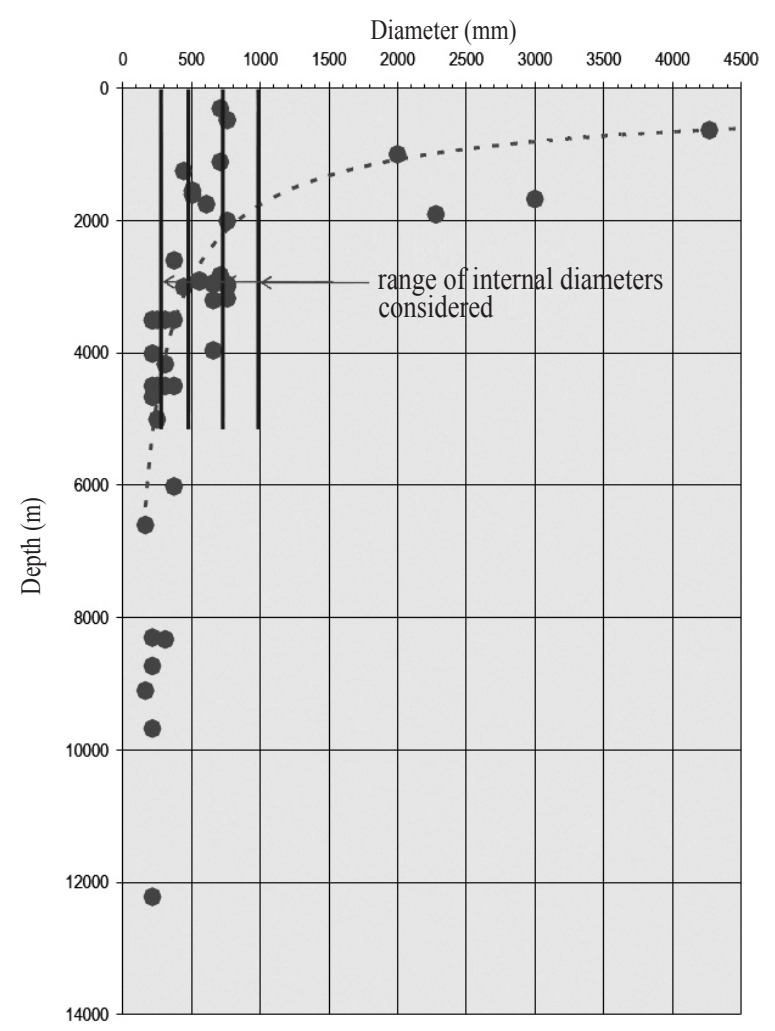

Fig. 3. Relationship between Borehole Depth and Diameter[7].

하므로 비용 측면에서 효율적이다. 이러한 부지특성조사는 시추공 처분 위치의 결정을 위한 초기 단계부터 수행되는데, 일반적으로 결정질 기반암에 대해 지하 $3 \sim 5 \mathrm{~km}$ 깊이의 지 질학적 정보가 부족한 경우가 많으므로 처분부지의 첫 번째 시추공은 그 깊이에서의 지질, 수리지질, 지질역사 등을 고 려한 부지적합성을 평가하는데 활용된다.

\section{3 심부시추공 처분개념 개발}

처분시스템 개념 개발은 처분용기, 시추 처분공 내 폐기 물 처분용기 적치 및 시추 처분공 밀봉/폐쇄 개념에 대한 도 출을 포함한다. 폐기물 처분용기의 경우 탄소강 튜브, 용접 플러그 덮개, 처분공 내에서 다른 처분용기와 연결하는 나사 형 연결부로 구성하여 고압의 수두 압력과 지온 환경 하에서 역학적 응력을 지탱할 수 있도록 개념을 설정하여 처분공이 폐쇄되기 전까지는 부식되지 않고 충분히 건전성을 유지하 도록 한다. 시추 처분공내 처분용기의 적치가 완료된 후에는 
처분구역 상부(심도 $3 \mathrm{~km}$ 지표까지)의 밀봉은 압축 벤토 나이트 밀봉재, 이음부 플러그, 시멘트 플러그 및 뒷채움재 를 설치하는 개념으로 한다.

\section{4 성능 및 안전성 평가 기술}

심부시추공 처분방식에서 안전성 평가는 2 단계로 수행 된다. 우선 수직방향의 지하수 흐름과 핵종 이동의 주 원동 력인 방사성폐기물의 붕괴열로 인한 압력 상승을 고려한 심 부시추공 처분시스템의 열역학적 해석이 핵종이동과 같은 안전성 평가에 선행되어 입력 자료로써 사용된다. 이를 바탕 으로 처분장으로부터 지하생태계까지의 핵종이동은 1 차원 이류-분산 방정식의 해석해를 이용하거나, GoldSim 프로그 램 등을 이용하여 모사한다[5].

\section{5 심부시추공 처분 특성}

이상에서 살펴본 심부시추공 처분 개념에 대한 처분심 도, 지하환경, 지질/지하수, 부지감시, 안전성 및 회수성 측 면에서의 특성은 Table 1에 간략하게 나타내었다.

Table 1. Characteristics of DBD

\begin{tabular}{cl}
\hline Items & Deep Borehole Disposal (DBD) Technology \\
\hline Depth & \multicolumn{1}{c}{$3 \sim 5 \mathrm{~km}$} \\
\hline $\begin{array}{c}\text { Underground condition } \\
\text { (Radionuclide solubility) }\end{array}$ & $\begin{array}{l}\text { Potential transport pathways to the biosphere } \\
\text { are very long } \\
\text { Geochemically reducing condition limits the } \\
\text { solubility of radionuclides and the corrosion } \\
\text { of canister }\end{array}$ \\
\hline $\begin{array}{c}\text { Geology/Groundwater } \\
\text { (Radionuclide transportation) }\end{array}$ & $\begin{array}{l}\text { Crystalline rocks are attractive for DBD } \\
\text { because of } \\
\text { - their large size and relatively homogeneous } \\
\text { nature, } \\
\text { high mechanical strength, } \\
\text { - high overburden pressures contribute to } \\
\text { sealing of some of the fractures. }\end{array}$ \\
\hline Safety & $\begin{array}{l}\text { Deep fluids also resist vertical movement } \\
\text { because they are density stratified. }\end{array}$ \\
\hline Retrievability & $\begin{array}{l}\text { Safety case is simple } \\
\cdot \text { To retrieve waste after closure is difficult }\end{array}$ \\
\hline
\end{tabular}

\section{3. 심부시추공 처분기술 연구사례}

고준위 방사성폐기물을 인간환경으로부터 장기간 격리 시켜 안전하게 관리하기 위하여 다양한 방법들이 고려되었 으며, 그러한 방법들 중에는 해양처분, 빙하처분, 우주처분, 심층처분 및 초장심도 시추공 처분 방법들이 있다. 이들 처 분 방안들에 대한 분석을 통하여 현재 수준의 기술 및 조건 으로 적용 가능한 심지층의 터널형 처분방안이 가장 안전한 방법으로 평가되었으며, 스웨덴과 핀란드는 이 방법의 상용 화를 위한 인허가 단계를 진행하고 있다. 이와 더불어 최근 심부시추공 굴착 기술의 급속한 발달로 심층 처분방안에 대 한 대안으로서 심부시추공 처분에 대한 연구가 의미있게 진 행 되고 있는 바, 본 논문에서는 심부시추공 처분시스템 개념 을 도출한 주요 국가별 연구사례를 종합적으로 분석하였다.

\section{1 미 국}

심부시추공 처분개념은 초기에 지하 수 킬로미터 깊이에 위 치한 결정질 암반에 사용후핵연료 또는 고준위폐기물을 처분 하기 위하여 제안되었다[8]. 본 논문에서 다루는 대부분의 개념 은 5 $6 \mathrm{~km}$ 정도 깊이까지 굴착한 심부시추공에서 각 시추처 분공의 하부 $3 \sim 4 \mathrm{~km}$ 심도에 폐기물을 처분하고 시추처분공 간의 간격은 수 백 미터 이격시킨 시스템을 기반으로 구성된다.

\subsection{1 초기 연구 : 1950년대 - 1970년대}

미국에서 처음의 심부시추공 처분에 대한 제안은 1957 년 액체형태의 폐기물에 대하여 심부시추공 처분 또는 지층 처분을 고려할 것을 권고한 미국 국립과학원(NAS : National Academy of Science)의 평가에 의해 제기되었으며, 이후 1974년에 고준위폐기물 처분 프로그램의 초기 시절에는 지 층처분 개념의 다양한 방안 중의 하나로 고려되었다[8]. 고 체 및 액체 고준위폐기물을 대상으로 하여 암반매질을 용융 시키는 개념을 포함하는 심부시추공 처분 방법으로서 심도 $16 \mathrm{~km}$ 의 심부시추공에 폐기물을 처분하는 것을 고려하였다. 이러한 연구는 미국 에너지부(DOE : Department of Energy) 의 주관으로 수행되었는데, 심부시추공 처분 개념은 그 당시 에 고려되고 있었던 다른 다양한 처분 개념들과 비교되었다.

심부시추공 처분개념의 주요 장점은 순환되는 지하수가 지상 생태계와 교류하지 않을 것으로 예상되는 심부에 고준 


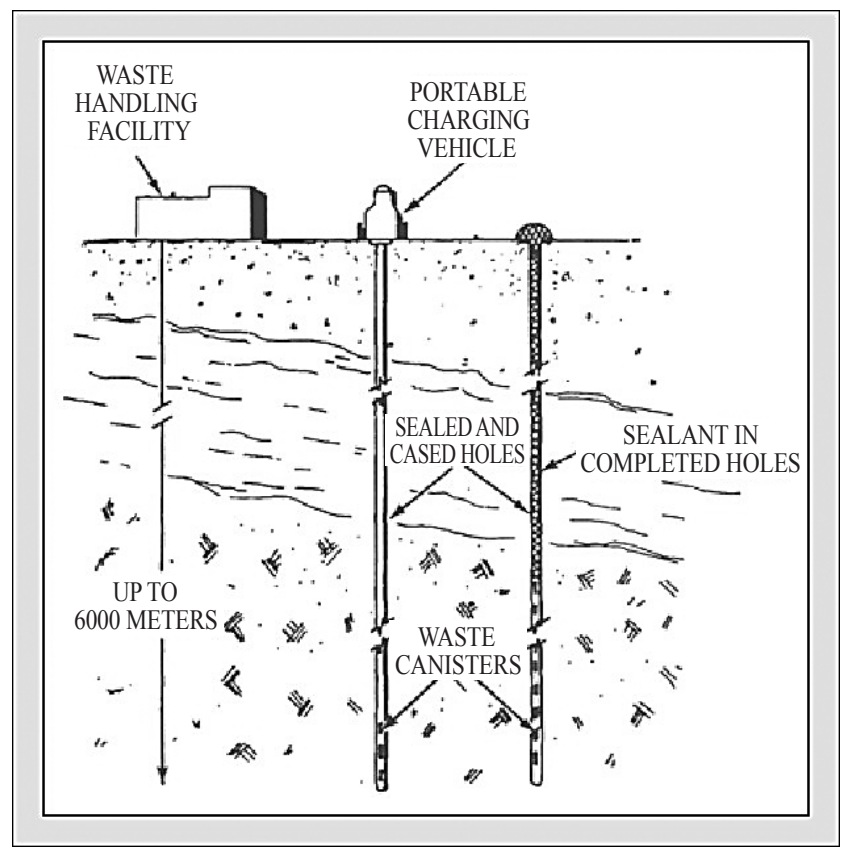

(a) A Concept for Solid Waste

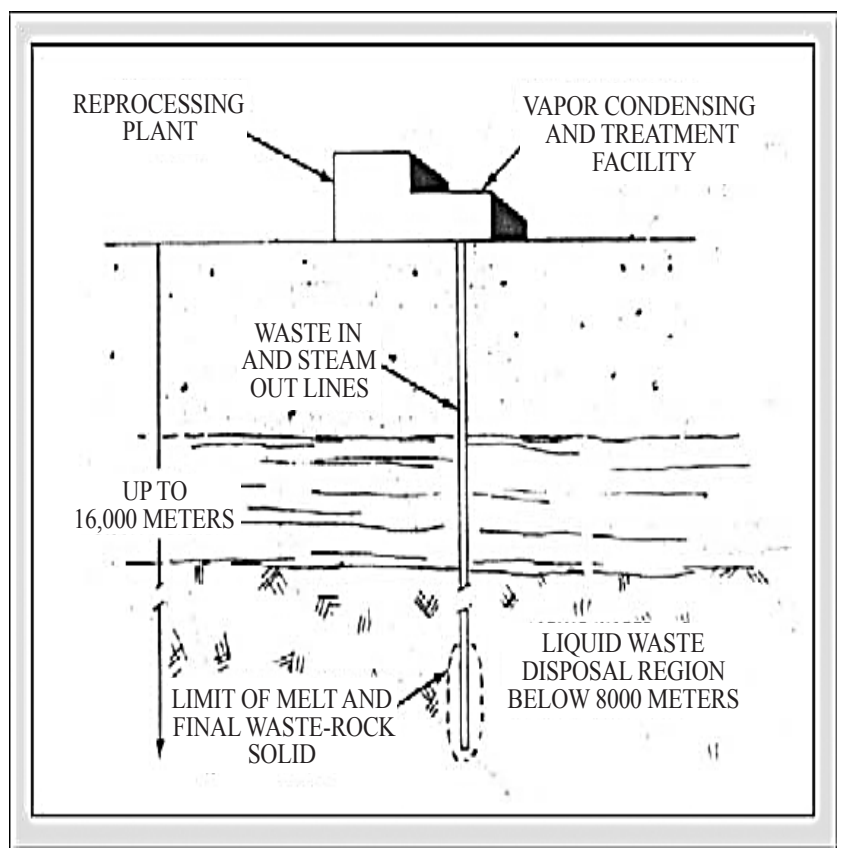

(b) A Concept for Liquid Waste

Fig. 4. Early Concepts of DBD in USA[9].

위폐기물을 처분한다는 것이다. 그 당시에는 이 개념이 대용 량의 초우라늄(TRU : Transuranic)폐기물 처분을 위한 적절 한 방법이 아닌 것으로 이해되었고, 요구되는 심도와 공경을 가진 다수의 시추처분공 굴착 가능성에 대한 불확실성이 존 재하였다. 심부시추공 처분 개념은 터널형 지층처분 및 해저 기반 처분 방법과 함께 미국 에너지부에 의해 상세한 분석 및 평가를 위하여 선정된 개념이다. 설정된 심부시추공 처분 개 념으로서는 처분대상을 고체폐기물, 액체폐기물에 따라 그 리고 처분방법을 암반 용융 여부에 따라 도출한 개념들로서 Fig. 4 에 나타낸 바와 같다[9].

\subsection{2 중기 연구 : 1980년대 1990년대}

심부시추공 처분에 대한 보다 심도있는 연구는 1981년에 미국 에너지부 원자력폐기물격리국(ONWI : Office of Nuclear Waste Isolation)의 용역을 받아 컨설팅회사인 WoodwardClyde에 의해 수행되었는데[10], 처분 초기시점으로 계획한 2000년까지 개발될 것으로 예상되는 처분기술을 가정하여 심 부시추공 굴착시스템 기술에 대하여 추정하였다. 처분개념은 지하수에 용해된 방사성 핵종은 아래와 같이 생태계에 도달 하기 전에 무해한 수준까지 붕괴한다는 가정에 근거하였다.
- 지하수의 이동은 매우 느려 흐름이동 경로는 매우 길다 - 지하수로 유입되는 방사성 핵종의 양은 매우 미약하다. - 방사성 핵종 이동은 매우 긴 흐름경로에 따라 암반과 화 학적 반응에 의해 지연된다.

- 이들 요소들의 조합은 방사성핵종의 방사능이 안전한 수준으로까지 붕괴될 때까지 생태계로부터 격리된다.

Woodward-Clyde에 의해 정의된 기준 심부시추공 처분시 스템은 Fig. 5에 도시되었으며 처분구역은 약 $3 \sim 6 \mathrm{~km}$ 임을 나 타내고 있다. 시추공 하부 약 $0.6 \mathrm{~m}$ 지름으로 심도 $6 \mathrm{~km}$ 까지 굴 착하는 기술은 당시의 굴착 능력 범위에 있는 것으로 판단되 었다. 또한, 최대 심도는 시추공의 안정성에 의해 제한되는데 약 $6 \mathrm{~km}$ 깊이 결정질 암반에서 고밀도의 시추이수를 포함하는 시추공은 안정한 것으로 평가되었다. 이 계획은 상부 $1.2 \mathrm{~km}$ 까지는 대구경 굴착 방식을 사용하고 최종 깊이까지는 전통적 인 회전식 굴착 방식을 사용하는 것으로 하였다. 이 시스템은 사용후핵연료를 처분하는 경우에 대해서는 각 시추공당 850 처분용기(약 $527 \mathrm{MTHM})$ 가 적치되어 당시의 전체 처분용량 68,000 MTHM에 대하여 128 개의 시추공이 요구되었다. 또한 고준위폐기물 처분의 경우에 대해서는 처분공당 850 처분용 기(약 $1,785 \mathrm{MTHM})$ 이 정치되어 38 개의 시추공이 요구되었다. 
고준위폐기물 지층처분 방안으로서 터널형 처분장 개념 이 선정되었지만 에너지부는 심부시추공 처분 개념도 추가 적으로 고려할 가치가 있는 것으로 평가하였다. 이에 따라 에너지부는 심부시추공 처분 개념에 대한 공학적 분석을 수 행하였고 시추공 굴착방법에 있어서 기술적인 진전이 있게 된다면 향후 터널형 처분장 개념과 유사한 타당성이 있는 것 으로 예상하였다. 이들 기술에 있어서 실질적인 진전이 있 었고 1990년대에는 에너지부는 무기급 플루토늄의 처분을 위하여 심부시추공 처분개념을 도출하였고, 이후에도 고준 위 방사성폐기물관리 프로그램으로 심층처분에 대한 우선적 인 타당성이 있는 대안으로 지속적으로 연구를 수행하여 왔 으나, 관련 기술에 대하여 실증연구를 수행한 적은 없었다.

\section{1 .3 최근 연구 : 2000 년대}

미국 샌디아국립연구소는 2009년도에 심부시추공 처분 개념에 대한 분석을 위하여 사용후핵연료 집합체를 처분대 상으로 하여 석유산업 또는 지열발전 산업에서 사용한 시추 공 굴착기술을 이용하여 수직으로 $5 \mathrm{~km}$ 깊이까지 굴착된 시 추공에서 $0.45 \mathrm{~m}$ 직경, 심도 $3 \sim 5 \mathrm{~km}$ 구간의 하부 $2 \mathrm{~km}$ 구

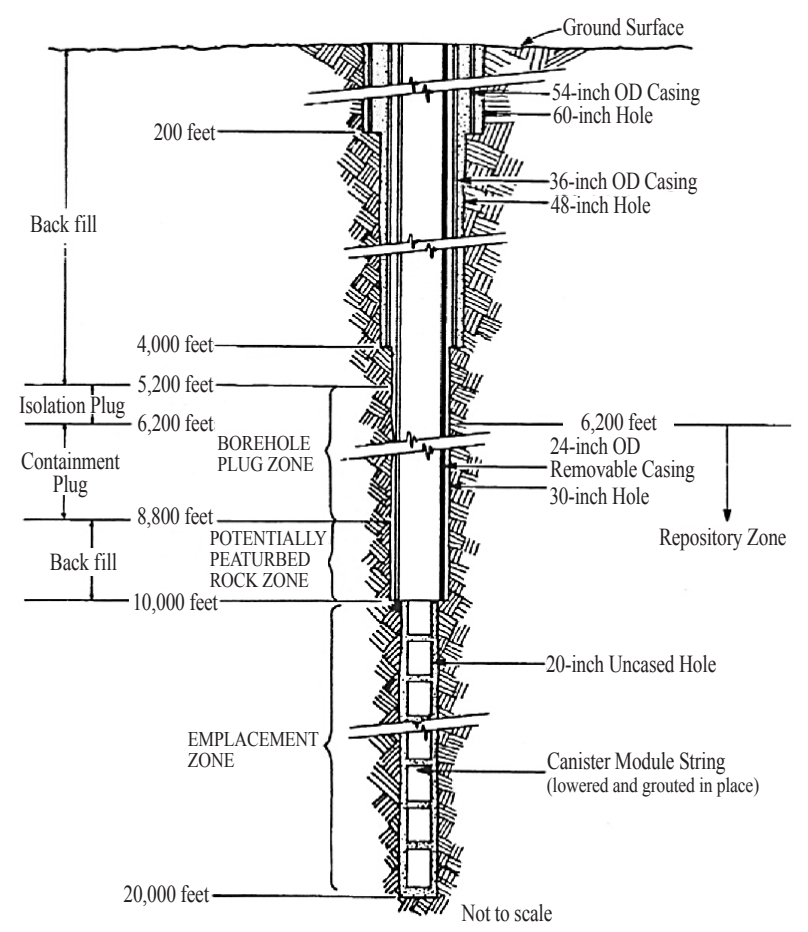

Fig. 5. ONWI DBD Concept[9].
역에 설치된 드릴케이싱 내부에 처분용기를 하강시켜 적재 하며, 적재가 완료되면 시추공은 밀봉하는 개념을 도출하였 다. Fig. 6은 샌디아국립연구소에서 개발한 심부시추공 처 분개념과 그에 따른 관정(Well) 설계 개념을 보여주고 있다. 또한, 이렇게 도출된 개념을 바탕으로 예비 안전성평가를 수 행하였는데, 1 단계로 열수리 해석을 통하여 고준위폐기물 붕 괴열에 의한 수직방향의 지하수 흐름을 시공간적으로 계산 하였다. 이 결과를 입력으로 하여, 2 단계 처분장으로부터 지 하생태계까지의 핵종이동은 1 차원 이류-분산 방정식의 해 석해를 이용하거나, GoldSim 프로그램[11]의 Contaminant Transport Module을 이용[12,13]하여 모사하였다. Fig. 7은 안전성평가를 위한 개념적 모델을 보여주고 있으며, Table 2 는 평가에 사용된 모델의 물성을 나타내고 있다.

또한, 2011년도에는 2009년도의 개념을 보다 구체화하 고 모든 개념 요소들의 실행가능성을 좀 더 완전하게 평가할 뿐만 아니라 기준설계에 대하여 성능 평가와 위험분석, 비용 예측을 수행하기 위하여 심부시추공 처분개념의 주요 구성 요소, 즉, 처분공 건설, 처분용기, 폐기물 적치, 처분공 밀봉 및 폐쇄에 관한 기준 설계안을 제안하였으며, 현재의 기술수
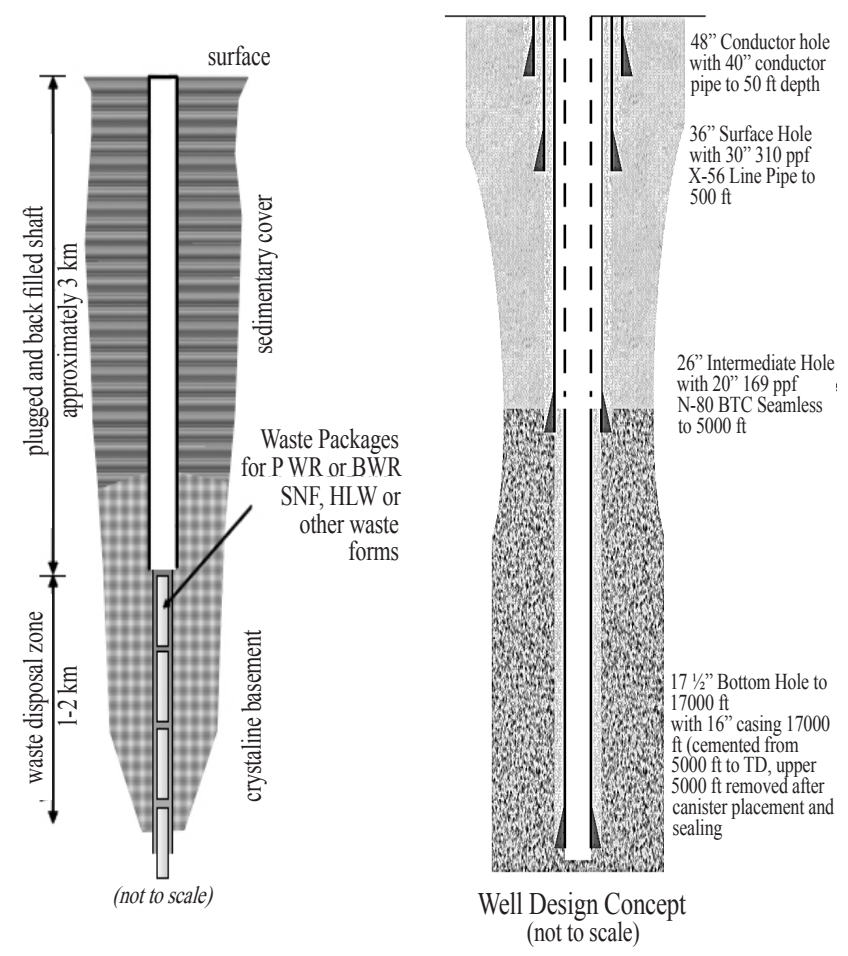

Fig. 6. SNL DBD Concept and Well Design Concept[5]. 
준으로 시행 가능한 방법으로 운반비용을 제외한 처분비용 을 산출하였다[6]. Fig. 8은 기준설계안의 처분공에 대한 개 념도와 처분구역 상부에서의 밀봉개념도를 나타낸다.

\section{2 스웨덴}

스웨덴 방사성폐기물관리기관 SKB는 사용후핵연료의 영구처분 방안도출을 위한 연구개발 프로그램으로서 다양 한 대안들에 대한 분석을 수행하였다. 심부시추공 처분에 대 한 타당성 평가와 이를 바탕으로 한 처분방안 결정을 위하

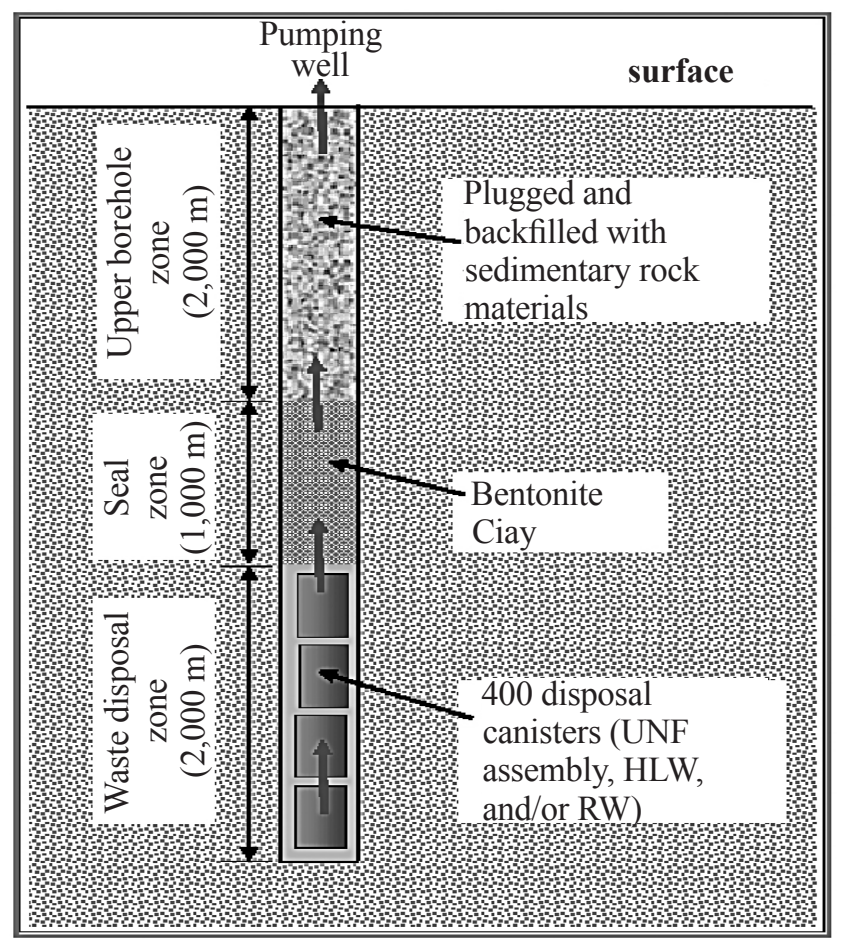

Fig. 7. Model Domain for the Performance Assessment of DBD[13].

Table 2. Material Properties for DBD Model[5]

\begin{tabular}{ccccc}
\hline Property & Bedrock & $\begin{array}{c}\text { Disturbed } \\
\text { Bedrock }\end{array}$ & $\begin{array}{c}\text { Sealed } \\
\text { Borehole }\end{array}$ & $\begin{array}{c}\text { Waste-Filled } \\
\text { Borehole }\end{array}$ \\
\hline Permeability $\left[\mathrm{m}^{2}\right]$ & $10^{-19}$ & $10^{-16}$ & $10^{-16}$ & $10^{-16}$ \\
\hline Density $\left[\mathrm{kg} / \mathrm{m}^{3}\right]$ & 2,750 & 2,750 & 2,750 & 2,750 \\
\hline $\begin{array}{c}\text { Specific heat } \\
{\left[\mathrm{MJ} / \mathrm{kg}^{-}{ }^{\circ} \mathrm{K}\right]}\end{array}$ & 790 & 790 & 760 & 760 \\
\hline $\begin{array}{c}\text { Thermal Conductivity } \\
{\left[\mathrm{W} / \mathrm{m}^{-}{ }^{-} \mathrm{K}\right]}\end{array}$ & 3.0 & 3.0 & 0.8 & 46.0 \\
\hline Porosity & 0.01 & 0.01 & 0.35 & 0.0001 \\
\hline
\end{tabular}

여 대안시스템 연구 프로젝트(PASS : Project on Alternative System Study)를 수행하였다.

\subsection{1 초기 연구(1980년대) : 심부시추공 처분 타당성 평가}

1987년부터 심부시추공 처분개념에 대한 타당성 평가를

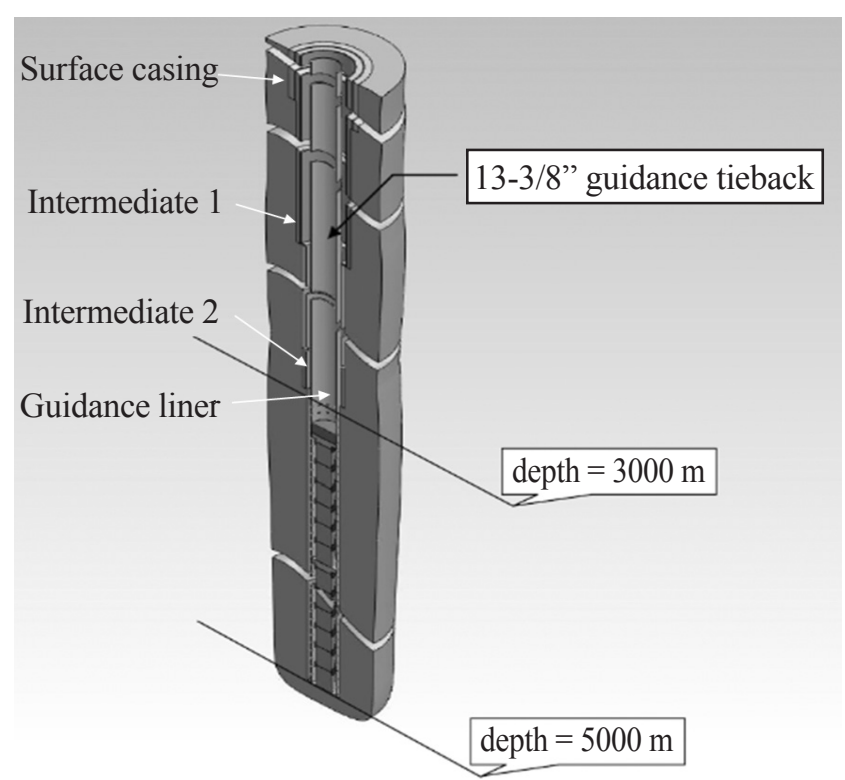

(a) A concept of DBD system designed by SNL

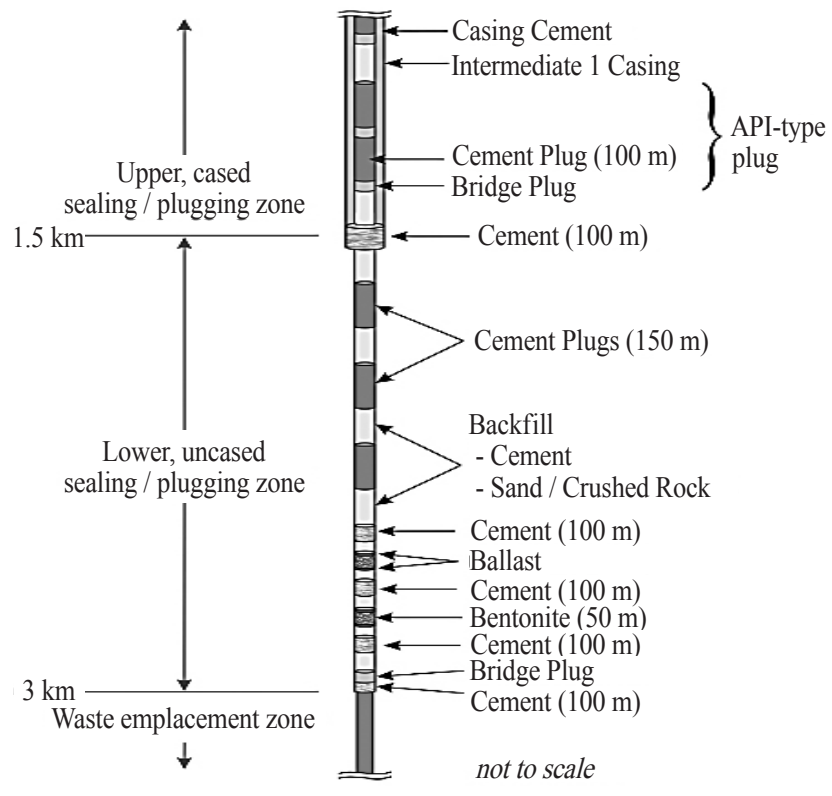

(b) A sealing concept of DBD system

Fig. 8. SNL Casing \& Sealing Concept for DBD System[6]. 
위한 기본적인 조사/분석을 수행하였으며, 개략적인 내용은 다음과 같다[14].

. 결정질 암반에서의 과학적 목적으로 굴착한 시추공 (Graverg-1) 검토

. 스웨덴 지하암반 $6 \mathrm{~km}$ 깊이까지의 지질학적 모델 설정

. 지질학적 조사 프로그램

. 암반역학적 고찰

상기 조사분석 내용 결과를 바탕으로 타당성 평가의 입력 자료로서 심부시추공 처분 개념 도출에 필요한 공학적 측면 의 기술개발을 수행하였으며, 관련분야는 아래에 기술하였다.

. 수리지질 모델링 주변에서의 온도 영역 해석

. 심부시추공 굴착 기술 분석

. 플러깅 및 밀봉 기술

. 부지 선정 방안 분석 및 비용평가

Fig. 9는 위에서 기술한 스웨 덴 초기의 타당성 분석을 위 한 기술개발로부터 도출한 처분구역에서의 처분용기와 벤 토나이트 블록 설정 및 처분구역 상부의 밀봉/플러깅 개념 을 보여주고 있다.

\subsection{2 중기연구 (1990년대) : 대안시스템 연구 프로젝트}

사용후핵연료 기준 처분시스템으로서 KBS-3 개념 개발 외에 스웨덴에서는 아래 3 가지 방안에 대하여 추가적으로 개념을 개발하고 이들 대안개념 설계에 대한 장단점을 분석 하였다[15].

- 심부시추공처분(Very Deep Holes : VDH) : 심도 2 $4 \mathrm{~km}$ 에 처분

- 장터널 처분(Very Long Holes : VLH) : 수 $\mathrm{km}$ 수평터널 에 비교적 큰 처분용기 처분

- 중길이터널 처분(Medium-Long Holes : MLH) : KBS-3 형 처분용기의 수평터널 처분

상기 4 개의 개념들에 대하여 당시 시점을 기준으로 처분 용기 제작/포장, 지하시설 건설 및 처분과 관련한 기술적 측 면, 장기 성능과 안전성 측면 및 비용 측면에서 비교분석하고 순위를 결정하였다. 이러한 비교를 위하여 개념을 개발한 심 부시추공 처분 시스템은 아래에 기술한 바와 같다.

\subsubsection{1 굴착 기술}

굴착은 석유관정 굴착기술과 Gravberg에서의 심부시추
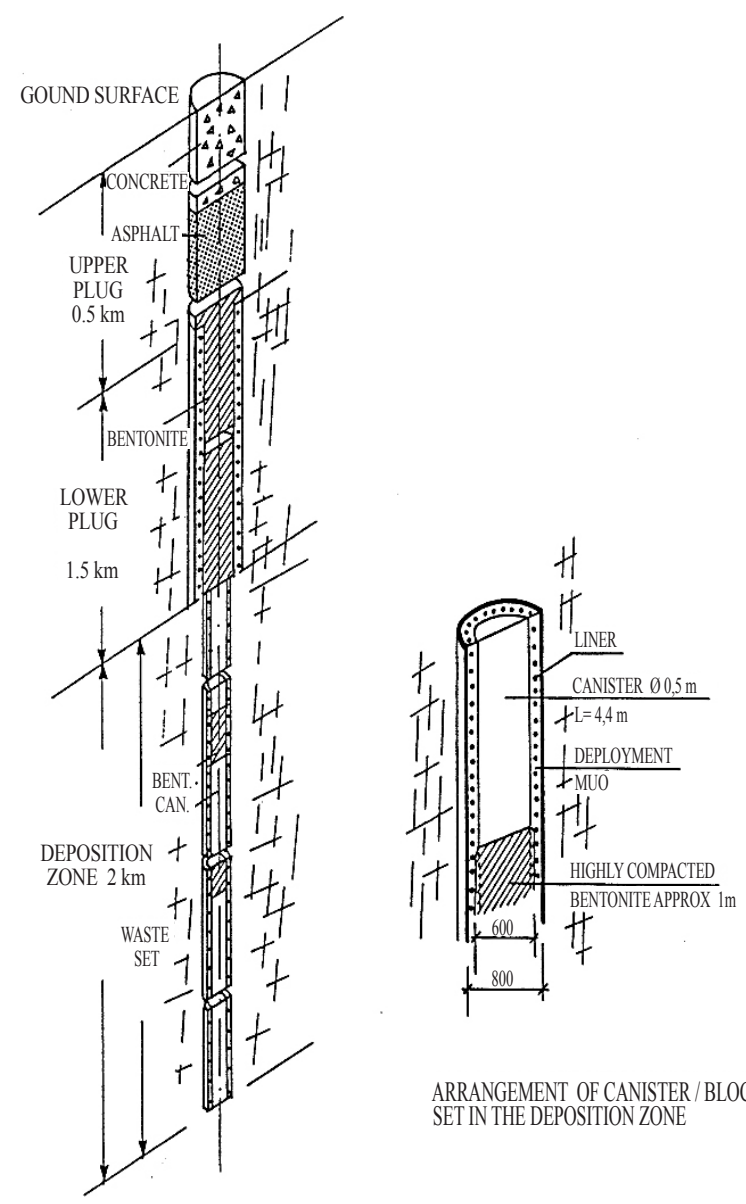

ARRANGEMENT OF CANISTER / BLOCK SETIN THE DEPOSITIONZONE

Fig. 9. Early Concept for DBD in Sweden[14].

공 굴착으로부터 얻은 추가적인 경험에 바탕을 둔다. 시추공 은 처분구역에서 $0.8 \mathrm{~m}$ 의 직경을 유지하며 이 직경은 $4 \mathrm{~km}$ 심도에서 굴착된 당시 시점에서 가능한 가장 큰 직경이다.

굴착은 해당 심도에서 시추이수로서 벤토나이트 이수를 함 께 수행하며, 필요한 케이싱은 석유산업에서 사용되는 철재대신 에 청동재를 사용한다. 이렇게 하여 부식을 감소시켜 수소가스 의 형성을 회피하며, 케이싱은 처분용기 주변의 빈 공간에 벤토 나이트가 전체적으로 채워질 수 있도록 다공성으로 제작한다.

\subsubsection{2 처분용기 정치기술}

처분용기를 정치시키는 한가지 가능한 방법은 굴착시 사 용된 것과 동일한 시추장비를 사용하는 것을 바탕으로 하고 있다. 처분용기를 드릴파이프의 굴착비트의 위치인 하단부 에 연결하고 고정시킨 후 처분용기 정치위치로 내려진다. 굴 
착시 사용되었던 벤토나이트 시추이수는 보다 진한 벤토나 이트 설치 머드에 의해 교체되고 그 두께는 캐니스터가 손상 받지 않고 머드를 관통하여 처분위치에 정치가 가능하도록 허용하는 두께로 한다. 고압축 벤토나이트 블록 사이에 2개 또는 그 이상의 처분용기를 연결하여 스트링(열)으로 만들고 이 스트링을 한번에 처분구역으로 정치시킨다. 벤토나이트 함량은 평균 벤토나이트 밀도가 팽윤시 그 위치에서 각 처분 용기를 유지시킬 수 있을 정도로 충분한 정도로 한다. 시추 공에서 처분용기의 위치를 점검하는 것은 매우 중요한데 석 유관정시 개발된 장비와 방법을 이용하여 수행될 수 있을 것 으로 판단하였다.

\subsubsection{3 밀봉 및 플러깅}

시추공의 상부 $2 \mathrm{~km}$ 부분은 시추공 케이싱 외벽 또는 내 부를 따라서 지하수가 축방향으로 유동하는 것을 막기 위 하여 밀봉하고 플러그를 설치한다. 시추공을 따라서 1 곳 또 는 그 이상의 지점에 시추공 주변에 혹시 있을 수도 있는 굴착 손상지역에 대한 보강이 필요할 수도 있다. 2 개의 다 른 플러깅 구역으로 구분될 수 있는데, 하부인 $2 \mathrm{~km}$ 에서부 터 $0.5 \mathrm{~km}$ 까지의 깊이에는 구멍들이 존재하는 케이싱 내부 에 압축된 벤토나이트 블록을 채운다. 블록은 가능한 한 벤 토나이트 머드 두께만큼 내려진다. 그 상부인 $0.5 \mathrm{~km}$ 에서부 터 지표까지는 아스팔트로 채워진다. 그 상부는 콘크리트 플 러그로 밀봉한다.

\subsubsection{4 심부시추공 처분시스템 설계}

심부시추공 처분 시스템에 대한 시추공의 처분구역 및 플러깅구역에 대한 개념은 Fig. 10 에서 보여주고 있다. 지하 수량이 많은 시추공 구역은 처분을 위한 용도로 사용하지 않 고, 벤토나이트로만 채워진다.

심부시추공 처분은 $0.5 \mathrm{~km}$ 간격의 다수의 처분을 위한 심부시추공으로 구성된다. 각 시추공의 지표 작업구간은 시 추장비, 이수취급 및 유지보수 등을 위한 공간이 요구된다. 사용후핵연료 집합체 밀집의 경우에는 19 개 처분 시추공이 필요하며, 사용후핵연료 집합체 비밀집의 경우에는 38 개 처 분 시추공이 필요한 것으로 평가하였다. 이때 면적은 각각 약 $3 \mathrm{~km}^{2}$ 또는 $7 \mathrm{~km}^{2}$ 이 소요되며, 도로, 전기 유틸리티, 용수 공급 및 배수 등은 각 굴착작업장 위치에 설치한다.

\subsection{3 최근 연구 (2000년대) : KBS -3 방안과 비교평가}

스웨덴 방사성폐기물 관리기관은 고준위폐기물 처분방 안 기준개념으로 KBS-3 개념을 설정하고 이에 대하여 30 년 이상의 연구개발 및 실증시험을 수행해 왔다. 그 결과 이 개 념은 2001년에 정부에 의해 사용후핵연료 처분방안으로 결정 되었다. 이 결정에서 최종처분을 위한 구체적인 방안의 최종 결정은 원자력활동법과 환경법에 따라 최종결정이 날 때까지 확정될 수 없다는 것을 강조하였으나, 정부의 입장은 KBS-3 방안을 사용후핵연료 최종 처분방안으로 고려하여왔다. 하 지만, 심부시추공 처분방안이 KBS-3 방안에 대한 비교되어 야 할 주 대안으로서 대중논쟁에서 최근 주목을 받아왔다.

2000년도에는 제안된 심부시추공 처분개념의 시추공 굴 착 가능성 분석에 대한 방사성폐기물 관리기관의 요구에 따 라 공학적인 타당성 분석이 수행되었다. 개념적인 시추공 설 계가 제안되고 시추공 설계에 필요한 모든 측면이 고려되었 는데, 심부시추공 처분개념에 대하여 독일 심부시추공 굴착 사업자인 Deutag사의 검토를 받은 바 있다[16].

또한 2006년도에는 심부시추공 처분개념을 바탕으로 한 사용후핵연료 처분장에서의 심부지하수 조건의 안정성을 조 사하기 위한 연구로서 심부지층 지하수의 열영향에 대한 해 석 및 분석을 수행하였다. 연구는 대안시스템연구 프로젝트 에서 설정된 심부시추공 처분장 설계에 근거하고 있으며, 아 래에 기술한 바와 같다[17].

처분용기는 사용후핵연료를 적재하고 지하 $4 \mathrm{~km}$ 에서 $2 \mathrm{~km}$ 심도에 정치하여 처분되는 것으로 가정하고 그 주위 는 벤토나이트와 물로 혼합된 슬러리로 충진된다. 처분용기 는 $1 \mathrm{~m}$ 길이의 압축 벤토나이트 블록으로 구성된 쿠션에 의 해 분리된다. 처분구역 상부 $2 \mathrm{~km}$ 는 벤토나이트와 아스팔트 및 콘크리트로 밀봉된다. 스웨덴 원자로 40 년 운영으로부터 발생할 것으로 예상되는 사용후핵연료를 처분하기 위해서는 각 처분공에는 300 개의 처분용기를 적재하며 총 45 개의 심 부시추공이 요구된다. 각 처분공은 사용후핵연료의 방사능 붕괴에 따른 붕괴열을 가진 열원이 작용하는 것으로 간주한 다. 지하수의 염도는 일반화된 분배계수로 깊이에 따라 변 하는 것으로 하여, 표면으로부터 $700 \mathrm{~m}$ 깊이까지의 지하수 는 염도가 0 인 것으로 가정하고, $700 \mathrm{~m}$ 에서 $1,500 \mathrm{~m}$ 깊이까 지는 지하수의 염도는 $0 \%$ 에서 $10 \%$ 까지 증가, $1,500 \mathrm{~m}$ 깊이 이하에서는 염도의 함유량이 $10 \%$ 인 것으로 가정한다. 지하 
수의 밀도는 대략 염도 함유량과 선형적으로 증가하는 것으 로 가정하는데 염도가 $10 \%$ 인 지하수는 순수물보다 $10 \%$ 정

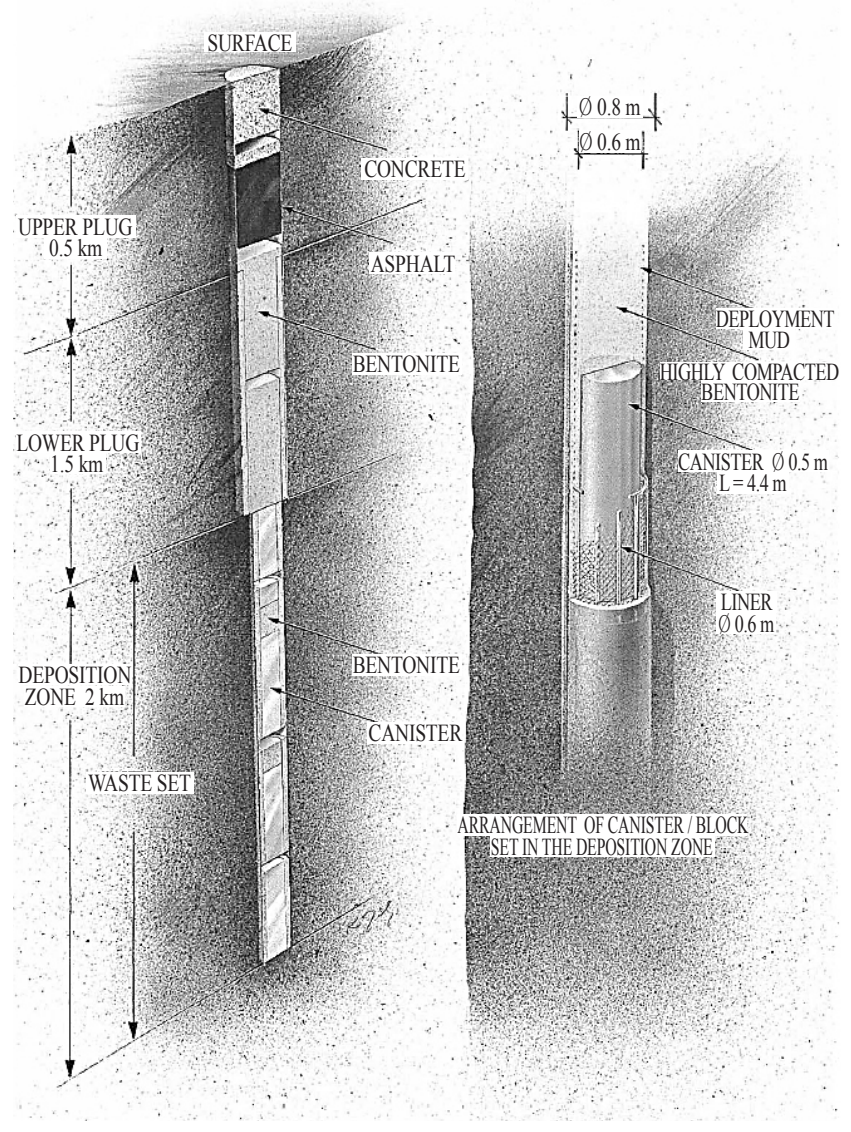

도 밀도가 높은 것으로 한다. 이로 인하여 지하수 시스템은 안정적인 층상을 구성하는데, 이러한 안정성을 변화시키기 위해서는 지하수 시스템에 어떠한 동인이 작용하여야 한다.

이에 대한 분석을 위하여 처분된 사용후핵연료로부터 발생하는 열, 균열대의 방향, 지표 수리경사의 다양한 조합 으로 인한 민감도에 대한 시험 등을 통하여 많은 수의 계산 을 수행하였다. 그 결과 일반적으로 고려된 입자들의 이동 시간은 극한적으로 장기간으로서 백만 년에서 일억 년 정 도인 것으로 계산되었다. 또한, 사용후핵연료로부터 발생 하는 열은 처분심도 암반에 존재하는 거의 정지상태 염도 지하수의 안정성을 변화시키기에는 불충분한 것으로 나타 났다. 그리고, 민감도 분석에서는 속도에 의한 영향, 흐름범 위 및 계산된 가상의 이동시간에의 영향을 보여주지만 그 차이는 처분장의 성능에 실질적인 영향을 주지는 않는 것 으로 판단하였다.

2010년도에도 KBS-3방법에 따른 사용후핵연료 처분과 심부시추공에 처분하는 방법에 대한 비교가 수행된다(Fig. 11). 목적은 두 방법에 대한 포괄적인 비교를 수행하는데 있 고, 그렇게함으로써 각각의 방법을 구별하는 정확한 인자를 도출하기 위한 것이었다. 본 비교연구에서 고려하는 심부시 추공 처분장의 설계는 1980년대 말에서 1990년대 초에 스웨 덴 방사성폐기물 관리기관에서 수행했던 대안시스템연구 프 로젝트 연구결과에 근거하며, 두 개념에 있어서 안전기능, 처분장 건설, 사용후핵연료 취급 및 핵물질보장조치 등의 관 점에서 분석한 바 있다[18].

Fig. 10. DBD Concept in Swedish PASS Project[15].

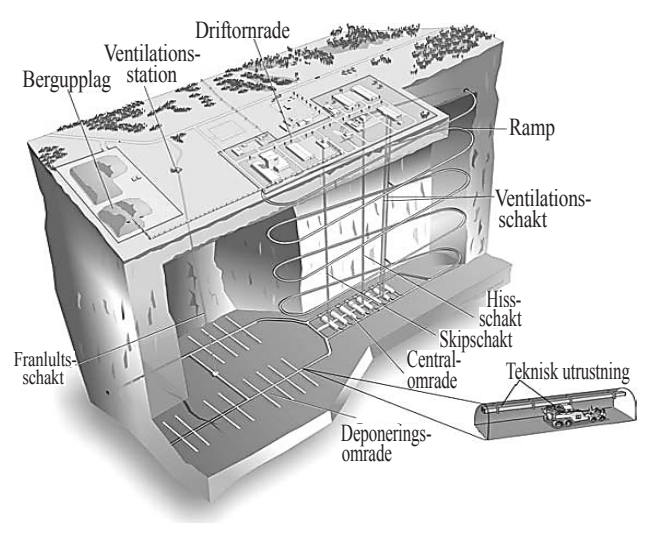

(a) KBS-3(DGD) concept

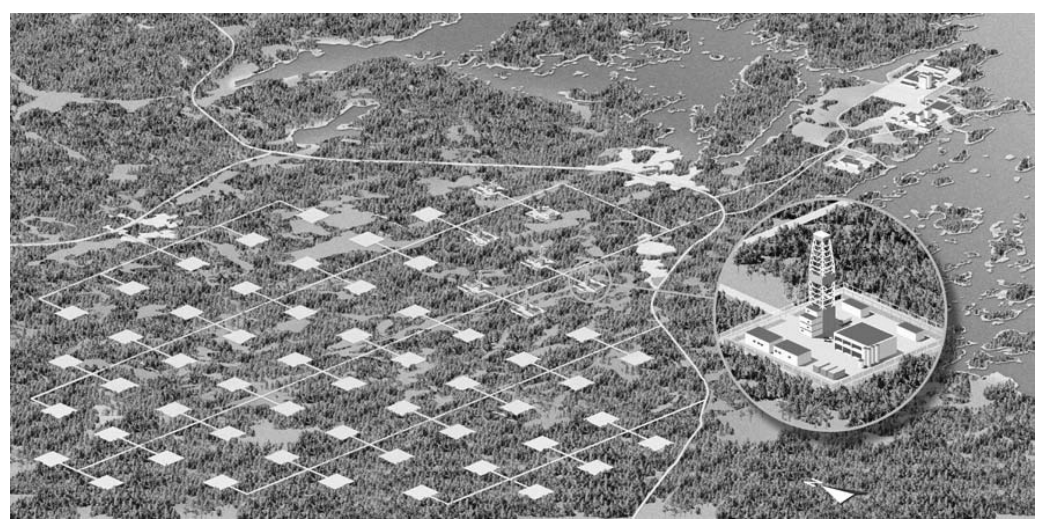

(b) DBD concept

Fig. 11. Swedish Concepts for DGD and DBD[18]. 


\section{3 덴마크, 네덜란드}

덴마크에서는 1980 년대 초부터 암염돔에서의 처분기술 에 관한 연구를 수행하였으며, 1999년에는 심부지층의 암염 층에서의 심부시추공 처분기술을 적용하는 개념을 도출하 여 장단점을 분석하였다[19]. 네덜란드에서도 동일한 시기에 대학을 중심으로 암염돔에서의 심부시추공 처분개념에 대한 연구를 수행한 바 있으며, 이들을 개략적으로 기술하면 다음 과 같다(Fig. 12).

- 고준위폐기물은 원통형 처분용기의 형태로 존재하며, 처 분용기의 크기는 길이 $1.4 \mathrm{~m}$, 지름 $0.43 \mathrm{~m}$ (부피 $0.2 \mathrm{~m}^{3}$ ) 이다. 각 처분용기는 유리화폐기물을 적재한 원통으로 구 성되는데, 이들은 두께가 앏은 금속재 오버팩에 포장된다. - 시추공은 오일 또는 가스 생산 또는 용해채광을 위한 굴착과 유사한 방법으로 암염층에 굴착한다. 후속적으 로 공은 전체 시추공 길이에 충분한 강도를 지닌 금속 관으로 케이싱을 한 후 금속관과 암반층 사이의 공간은 시멘트로 채운다. 이러한 방법으로 $50 \mathrm{~m}$ 에서 수백 미터 까지의 길이를 가진 적절한 시추공을 생성한다. 시추공 은 시추이수로 채워지는데 이 단계에서 암염층의 용해 를 막기 위해 이수는 고농도의 염분을 포함하도록 한다. - 다음단계는 시추공에 폐기물 처분용기를 정치하는 공정 이다. 이 공정은 와이어라인을 이용하여 수행될 수 있지 만 처분용기 자체의 무게를 이용하여 각 처분용기를 내 려가게 할 수 있다. 시추공의 처분구역이 처분용기로 채 워진 후, 시추이수는 시멘트로 교체한다(대안개념으로서 다수의 처분용기 처분, 처분구역에 대한 시추이수를 시 멘트로 대체, 2 번째 배치의 처분용기 처분 및 시멘팅 등). - 최종단계는 시추공의 케이싱된 부분에 대한 폐쇄 및 밀 봉으로서 석유산업에서 사용된 방법들과 유사한 방법 이 사용될 수 있다. 적절한 개념은 각 길이가 $50 \mathrm{~m}$ 인 3 개의 시멘트 플러그를 설치하는 것으로, 하나는 케이싱 된 시추공의 가장 아래 부분, 하나는 시추공의 최상부 및 하나는 중간이며, 플러그 사이 공간은 물로 채운다.

\section{4. 결 론}

사용후핵연료 또는 고준위폐기물을 생태계로부터 장기

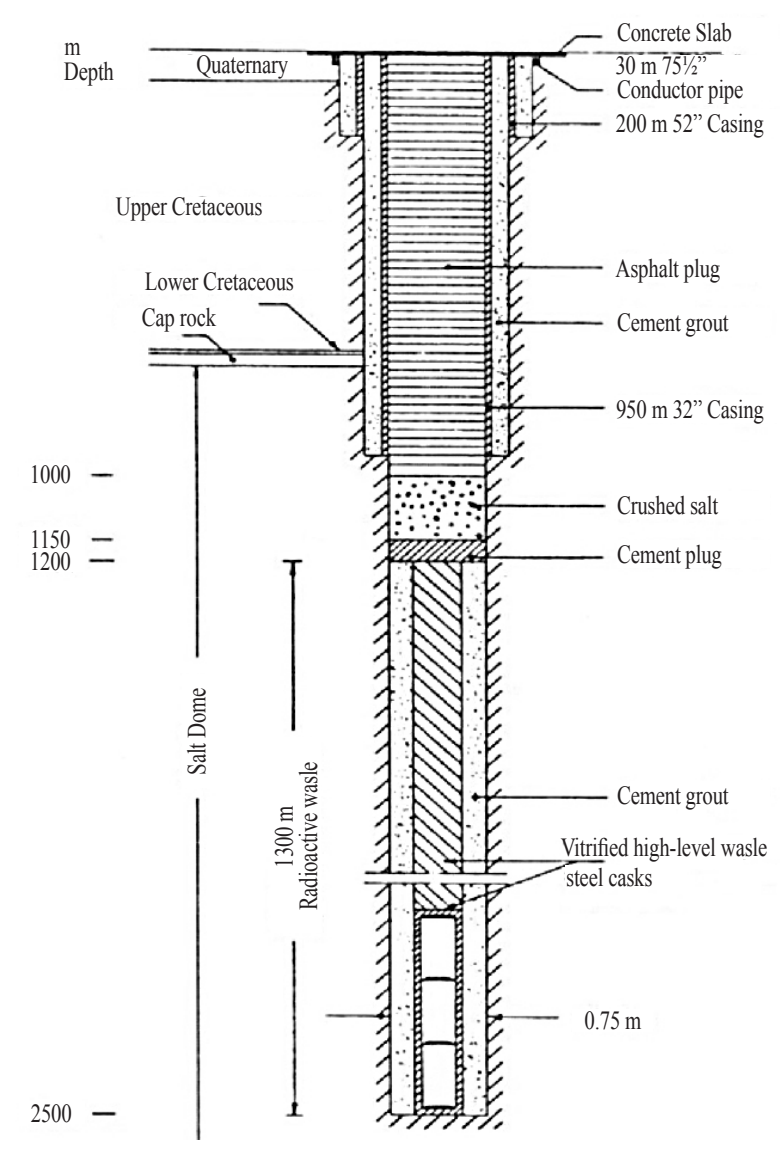

Fig. 12. DBD Concept in Salt Rock Formation[19].

간 동안 안전하게 격리시키기 위한 방법으로서 현재의 기술 단계에서 심도 $500 \mathrm{~m}$ 깊이의 터널형 처분시스템(KBS-3 타 입)이 가장 안전한 것으로 고려되고 있고, 스웨덴과 핀란드 에서는 이를 시행하기 위한 인허가 절차가 진행 중인 상용화 단계에 있다. 그럼에도 불구하고 최근 심부 시추기술의 비약 적인 발전으로 보다 안전하고 경제성있는 대안 기술로서 심 부시추공 처분기술에 대한 연구가 의미있게 진행되고 있다.

본 논문에서는 최근 심부 시추기술의 비약적인 발전에 따라 터널형 처분시스템인 KBS-3타입에 대한 유력한 대안 기술로서 평가되고 있는 심부시추공 처분 시스템에 대한 일 반적인 개념과 해외 기술개발 사례를 분석 정리하였다.

- 미국과 스웨덴은 자국에 적합한 심부시추공 처분시스 템 개념을 개발하고 요소기술 별로 상세한 분석을 수행 한 바 있다. 또한, 네덜란드와 덴마크의 경우 화강암이 아닌 암염층에서의 심부시추공 개념에 대한 연구가 수 
행되었다.

- 상용화 단계에 있는 심층 처분시스템 기술은 현재의 기 술로 실증을 완료한 기술임에 비하여 심부시추공 처분 은 개발하여야 할 기술과 이에 대한 실증이 필요한 것으 로 전문가들은 평가하고 있다. 이를 위하여 미국에서는 심부시추공 처분 방법에 대한 실증 로드맵을 마련하고 이를 시행할 계획에 있다.

실증단계를 완료하고 상용화 단계인 심층 처분에 비하 여 심부시추공 처분은 지금까지 개념적인 개발단계에 있어 시스템에 대한 불확실도가 크기 때문에 비교대상이 되지 않 는다는 평가도 나오고 있다. 따라서, 심부시추공 처분 개념 을 국내에 적용하고자 할 경우 이에 대한 불확실도를 줄이고 정확한 평가를 수행하기 위해서는 국내 고유의 시스템 설정 과 세부기술별로 상세한 실증연구 계획을 수립하여 이행하 는 것이 필요하다.

\section{REFERENCES}

[1] Karl-Inge ÅAhäall, Final Deposition of High-level Nuclear Waste in Very Deep Boreholes, Swedish NGO Office of Nuclear Waste Review(MKG), MKG Report 2 (2006).

[2] Annika Olofsdotter, Vetenskapsjournalisterna, Deep boreholes; An alternative for final disposal of spent nuclear fuel, Report from KASAM, pp. 9-11, Report 2007 (2007).

[3] Blue Ribbon Commission, Blue Ribbon Commission on America's Nuclear Future, pp. 29-31, Report to the Secretary of Energy (2012).

[4] W. Arnold, P. Vaughn, R. MacKinnon, and P. Brady, Research, Development, and Demonstration Roadmap for Deep Borehole Disposal, US DOE, Used Fuel Disposition, FCRD-USED -2012-000269 (2012).

[5] P. Brady, B. Arnold, and P. Swift, Deep Borehole Disposal of High-Level Radioactive Waste, Sandia National Laboratories Report, pp. 21-48, SAND2009-4401 (2009)
[6] Bill W. Arnold, Patrick V. Brady, and Stephen Pye, Reference Design and Operations for Deep Borehole Disposal of High-Level Radioactive Waste, Sandia National Laboratories Report, SAND2011-6749 (2011).

[7] John Beswick, Status of Technology for Deep Borehole Disposal, Contract No. NP 01185, pp. 16-18, EPS International (2008).

[8] National Academy of Sciences(NAS), The Disposal of Radioactive Waste on Land, http://www.nap.edu/openbook.php?record_id=10294 (1957).

[9] NIREX, A Review of the Deep Borehole Disposal Concept for Radioactive Waset, Nirex report no. N/108, Oxfordshire, UK (2004).

[10] Woodward-Clyde Consultants, Very Deep Hole Systems Engineering Studies, Technical Report, ONWI (1983).

[11] GTG(GoldSim Technology Group), GoldSim Probabilistic Simulation Environment User's Guide, Version 10.5. Volumes 1 and 2. GoldSim Technology Group LLC, Washington (2010).

[12] T. Hadgu, B. Arnold, J. Lee, G. Freeze, P. Vaughn, and P. Swift, "Sensitivity Analysis of Seals Permeability and Performance Assessment of Deep Borehole Disposal of Radioactive Waste", PSAM11 ESREL 2012, pp. 2138-2147, Helsinki, Finland (2012).

[13] P. Swift, B. Arnold, P. Brady, G. Freeze, T. Hadgu, and J. LEE, "Preliminary Performance Assessment for Deep Borehole Disposal of High-Level Radioactive Waste", MRS Proceedings, Vol. 1475 (2012).

[14] C. Juhlin and H. Sandstedt, Storage of Nuclear Waste in Very Deep Boreholes: Feasibility Study and Assessment of Economic Potential, SKB Report, TR 89-39 (1989).

[15] SKB, Project on Alternative Systems Study Final Report, SKB Report, TR 93-04 (1993).

[16] Tim Harrison, Very Deep Borehole Deutag's Opinion on Boring, Canister Emplacement and Retrievability, SKB Report, R-00-35 (2000).

[17] Niko Marsic, Bertil Grundfelt, and Marie Wiborgh, 
Very Deep Hole Concept-Thermal Effects on Groundwater Flow, SKB Report, R-06-59 (2006).

[18] SKB, Jämförelse mellan KBS-3-metoden och deponering i djupa borrhål för slutligt omhändertagande av använt kärnbränsle, SKB Report, R-19-13 (2010).

[19] Elsam Elkraft, Disposal of High-level Waste from Nuclear Power Plants in Denmark Salt Dome Investigations, vol. 5, ELSAM Frederica, Denmark (1981). 